\title{
Monotonicity and the limits of disharmony ${ }^{1 *}$
}

\author{
Péter Rebrus and Miklós Törkenczy \\ Research Institute for Linguistics, Hungarian Academy of Sciences (MTA) \\ Eötvös Loránd University (ELTE)
}

\section{Introduction}

In this paper we examine the role morphological complexity can play in vowel harmony. In the literature on vowel harmony, morphological constituency is typically referred to (i) in the identification of the domain of harmony and (ii) when patterns of harmony within morphologically simplex and complex domains are compared. In the first type of inquiry the question to be answered is whether harmony applies within the root, the word, some other morphologically identifiable domain, or more than one of these domains. In the latter case the question is whether there are differences between the harmonic patterns within the root (a morphologically simple word) and those found in words that consist of a root plus an affix attached to the root.

Here we focus on a different aspect in which morphological complexity can be relevant: the relationship between the harmonic properties of a stem and the harmonic properties of a stem derived from it by (inflectional or derivational) affixation. Let us say that the harmonic class of a stem or a type of stem is the harmonic value of the affix alternant it combines with. Thus, in the case of the front/back harmony (which we analyse here) the harmonic class of stems of a given type is front if they require the value front $(F)$ in a harmonically alternating suffix, and back if they require the value back $(B)$ in a in a harmonically alternating suffix. In the paper we will analyse variation in the transparent and antiharmonic behaviour of neutral vowels in Hungarian front/back harmony and show that a constraint (Harmonic Uniformity) that governs the relationship between the harmonic class of a stem and more complex stems derived from it creates subpatterns within the harmonic system in the same way as other aspects of morphological complexity, such as the difference between harmony in a morphologically simplex vs. a complex domain (cf. (ii) above), can realise different subpatterns within a harmony system (e.g. in Finnish, cf. Kiparsky and Pajusalu 2003).

We have argued elsewhere (Rebrus and Törkenczy 2014a, b, 2015, to appear) that the attested (i. e. wellformed) front/back harmony systems (cf. Kiparsky and Pajusalu 2003) conform to a general principle of monotonicity and that the unattested front/back harmony systems are non-monotonic. We consider vowel harmony targeting suffixes as a function that assigns harmonic values ( $F$ and $B$ in front/back harmony) to stem-types that are harmonic contexts for suffix harmony and assume that there is a universally fixed scale of harmonic contexts whose extreme positions are the "prototypical" contexts for the two harmonic values (the contexts $\mathrm{B}]_{\text {_ }}$ and $\left.\mathrm{F}\right]_{-}$in front/back harmony). The intermediate positions between the prototypical ones are "mixed" contexts that involve neutral vowels $(\mathrm{N})$ :

(1) Frontness/backness scale of stem contexts

$$
\left.\left.\left.\left.\mathrm{B}]_{-}<\mathrm{BN}\right]_{-}<\mathrm{N}\right]_{-}<\mathrm{FN}\right]_{-}<\mathrm{F}\right]_{-} .
$$

Given this fixed "frontness/backness scale", the monotonicity constraint on the assignment function will only permit those patterns of harmonic values assigned to the harmonic contexts that only contain contiguous series of the harmonic values $F$ and $B$. This, together with a further requirement that the prototypical contexts must have prototypical values, give us a perfect fit with the attested types of invariable front/back harmony systems reported in Kiparsky and Pajusalu (2003).

1 The authors would like to thank Hans-Martin Gärtner, Péter Siptár and Ildikó Szabó for their comments on a previous version of this paper. This work has been supported by the National Scientific Grant OTKA-104897 "Variation in Phonology." 
(2) Attested harmony patterns are contiguous

\begin{tabular}{|l|c|c|c|c|c|}
\hline \multicolumn{1}{|c|}{ stem contexts: } & $\mathrm{B}]_{-}$ & $\mathrm{BN}]_{-}$ & {$[\mathrm{N}]_{-}$} & $\mathrm{FN}]_{-}$ & $\mathrm{F}]_{-}$ \\
\hline attested language types: & & & & & \\
\hline a. opacity, no anti-harmony (E. Khanty) & $B$ & $F$ & $F$ & $F$ & $F$ \\
\hline b. transparency, no anti-harmony (Finnish) & $B$ & $B$ & $F$ & $F$ & $F$ \\
\hline c. transparency, anti-harmony (Uyghur) & $B$ & $B$ & $B$ & $F$ & $F$ \\
\hline d. "anti-opacity", anti-harmony (E. Vepsian) & $B$ & $B$ & $B$ & $B$ & $F$ \\
\hline \multicolumn{1}{|c|}{ unattested language types: } & & & & & \\
\hline e. opacity, anti-harmony & $B$ & $F$ & $B$ & $F$ & $F$ \\
\hline f. "anti-transparency", no anti-harmony & $B$ & $F$ & $F$ & $B$ & $F$ \\
\hline g. "anti-transparency", anti-harmony & $B$ & $B$ & $F$ & $B$ & $F$ \\
\hline h. "anti-opacity", no anti-harmony & & & & & $B$ \\
\hline
\end{tabular}

In the paper we will show that the monotonicity requirement can be extended to variable harmony systems and that the Hungarian variable front/back harmony pattern and the morphological complexity related subpatterns that result from Harmonic Uniformity conform to monotonicity.

\section{Variation in Hungarian front/back harmony}

Variation in Hungarian vowel harmony has been studied in detail (Ringen \& Kontra 1989, Hayes \& Cziráky Londe 2006, Hayes et al. 2009, Kálmán, Rebrus \& Törkenczy 2012, Rebrus et al. 2012, Törkenczy et al. 2013, Rebrus \& Szigetvári 2013, Blaho \& Szeredi 2013, Forró 2013). Basically there are three kinds of variation: (i) lexical variation in anti-harmony, (ii) vacillation due to the "Count Effect" (that a sequence of neutral vowels is variably less transparent than a single one) and (iii) vacillation due to the "Height Effect" (the tendency that more open neutral vowels are more variably transparent than less open ones (even when only one occurs)). Here we will only discuss (i) and (ii) and will abstract away from (iii).

2.1 Variation in anti-harmony Anti-harmony is a type of disharmony. It occurs when a stem containing only neutral vowels (an '[N]-stem') takes a harmonically alternating suffix with a back harmonic vowel: [[N]B]. In Hungarian it is the lexical property of an $[\mathrm{N}]$-stem whether it takes the front or the back alternant of a harmonic suffix: $[[\mathrm{N}] \mathrm{B} / \mathrm{F}]$, i. e. it is a case of lexical variation, as shown by the following examples: hir /hi:r/ 'news' and sir

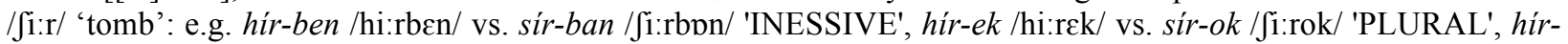
töl /hi:rtø:1/ vs. sir-tól/fi:rto:1/ 'ABLATIVE', hír-ünk/hi:rynk/ vs. sir-unk/fi:runk/ 'PL1.POSS'. This is a harmonic pattern in which two harmonic values, $B$ and $F$, are assigned to one harmonic context, which, in our case, is the harmonic context [N]. This is shown in (3) below, where the occurrence of both harmonic values $B \mid F$ in one cell represents lexical variation.

(3) Lexical variation in anti-harmony in Hungarian

\begin{tabular}{|r|c|c|c|c|c|}
\hline stem contexts: & $\mathrm{B}]_{-}$ & $\mathrm{BN}]_{-}$ & {$[\mathrm{N}]_{-}$} & $\mathrm{FN}]_{-}$ & $\mathrm{F}]_{-}$ \\
\hline transparency, variable anti-harmony & $B$ & $B$ & $\boldsymbol{B} \mid \boldsymbol{F}$ & $F$ & $F$ \\
\hline
\end{tabular}

Anti-harmony in Hungarian is constrained (i) lexically, (ii) vocalically, (iii) prosodically and (iv) morphologically.

(i) Lexical limitation means that monomorphemic anti-harmonic stems belong to a closed lexical class. This means that anti-harmony is not productive in the sense that if an all-neutral word is a recent borrowing, a proper name or a nonce word whose neutral vowel is $/ \mathrm{i} /, / \mathrm{i}: /$, then productive suffixation always involves the front harmonic suffix allomorph, e. g. dzsip-je /dzipje/ 'his/her jeep', kviz-ek/kvi:zek/ 'quiz-PL', Minszk-ben /minskben/ 'in Minsk', 
Trier-ben /tri:rben/ 'in Trier'. This fact, however, does not mean that harmonic back suffixation after all-neutral stems is rare (measured in type or token frequency). More than one fourth of monosyllabic monomorphemic free stems that are suffixable and contain /i i:/ (monosyllabic [i(:)] stems) are anti-harmonic $(26.3 \%=45 / 171)$. About half of all the monosyllabic [i(:)] stems are recent loanwords (none of which are anti-harmonic). If we disregard these novel items, the ratio of anti-harmonic monosyllabic [i(:)] stems will be $54.2 \%(45 / 83)$. If we focus on verbal monosyllabic [i(:)] stems, 76.7\% of them are anti-harmonic (23/30). In the light on these facts about frequency, the traditional assumption (e.g. Szépe 1969, Vago 1980) that anti-harmony in Hungarian is simply an irregular/exceptional phenomenon which is not essentially relevant to the overall (dis)harmony pattern of Hungarian is not tenable. Productivity can be viewed as a consequence of frequency: since the three fourths of monosyllabic [i(:)]-istems are not anti-harmonic, the productive pattern is front suffixation. ${ }^{2}$

(ii) The vowels of anti-harmonic stems in Hungarian are constrained too: they almost always are /i/ or /i:/, or very rarely /e:/. The other front vowels $/ \varepsilon, y, y:,, \varnothing: /$ do not occur. ${ }^{3}$ Anti-harmony with back stem vowels does not occur either: there are no back vowel stems which are consistently suffixed by (non-neutral/harmonically alternating) front vowel suffixes: $*[[\mathrm{~B}] \mathrm{F}]$. There are only two free stems with /e:/ that are anti-harmonic: they are héj /he:j/ 'peel' and cél /tse:l/ 'target'. The type frequencies for /i/ and /i:/ are 11 and 34, respectively (these stems-are nouns, adjectives or verbs).

(iii) The third restriction on anti-harmony is prosodic. All the monomorphemic anti-harmonic stems are monosyllabic, i. e. [i(:)] stems of more than one syllable get front harmonic suffixes obligatorily, e. g. kicsi-nek/*-ok /kifinck/ 'small-DAT', fiktiv-ek/*-ak/*-ok/fikti:vek/ 'pewit-DAT', bicikli-vel/*-val /biciklivel/ 'with bicycle'. ${ }^{4}$ This difference of harmonic behaviour requires that in Hungarian we should split the all-neutral stem context [N] into two harmonic contexts as distinct positions on the frontness/backness scale (1): one for monosyllabic, and another for polysyllabic all-neutral stems: $[\mathrm{N}]$ and $\left[\mathrm{NN}^{+}\right]$. We will call this effect (this division in the lexical distribution of antiharmonic roots) the Polysyllabic Split. We can hypothesize that these two positions are in a strict linear order on the scale: $[\mathrm{BN}]<[\mathrm{N}]<[\mathrm{NN}]<[\mathrm{FN}]$. Since a new stem context ([NN]) is introduced, now we have six harmonic contexts to which values are assigned, therefore we will get harmonic patterns with 6 positions on the scale. This pattern is shown in (4) below.

(4) No anti-harmony after polysyllabic monomorphemic all-neutral roots in Hungarian

\begin{tabular}{|l|c|c|c|c|c|c|}
\hline stem contexts: & $\mathrm{B}]_{-}$ & $\mathrm{BN}]_{-}$ & {$[\mathrm{N}]_{-}$} & {$\left[\mathrm{NN}^{+}\right]_{-}$} & $\mathrm{FN}]_{-}$ & $\mathrm{F}]_{-}$ \\
\hline variation only with [N] (Hungarian) & $B$ & $B$ & $\boldsymbol{B} \mid \boldsymbol{F}$ & $\boldsymbol{F}$ & $F$ & $F$ \\
\hline
\end{tabular}

(iv) The fourth restriction on Hungarian anti-harmony is morphological. The pattern in (4) above shows antiharmony in suffixes after monomorphemic stems. Now, if we consider harmony after suffixed stems we will find that morphological complexity in fact does not limit the scope of anti-harmony, but broadens it. Consider the paradigm uniformity constraint in (5) below which governs the harmonic behaviour of multiply suffixed forms, see Törkenczy, Rebrus \& Szigetvári (2013), Rebrus \& Szigetvári (2013).

2 (i) The verb is the only grammatical category in which [i(:)] stems are predominantly anti-harmonic, thus we expect that this class should show productive anti-harmonic behaviour. Unfortunately. this expectation cannot be verified because productivity in Hungarian is only testable for forms that cannot take verbal suffixes (non-verbs) because in present-day Hungarian new monomorphemic verbs cannot be borrowed (or coined), they must have a verb-forming suffix. The roots of these derived stems are certainly not verbal and any suffixes that are attached to them harmonise with the verb-forming suffix. (ii) Hayes et. al. (2006) have tested the $B$-preference of monosyllabic /i:/-words in a wug test (primarily designed for testing other constraints), but their results were inconclusive.

3 Except the obsolete vacillating pronunciation of forms ${ }^{\%}$ Svejc / $v$ vejts/ 'Switzerland' and ${ }^{\%}$ spejz / Sprjz/ 'pantry'.

4 Potential counterexamples are férfi /fe:rfi/ 'man' and derék/dcre:k/ 'waist'. Both take back suffixes obligatorily in certain forms: férfi-ak/*ek/fe:rfipk/ 'man-PL' and derek-am/*em /derekpm/ 'waist-1SG.POSS'. With other suffixes, however, vacillation occurs: e.g. férfi-val/vel 'with (a) man', derék-ban/ben 'in waist'. 


\section{(5) Harmonic Uniformity}

The harmonic class of a suffixed stem is identical to the harmonic class of its root, i.e. $[[\mathrm{X}] \mathrm{F}] \Rightarrow[[[\mathrm{X}] \mathrm{Y}] \mathrm{F}]$ and $[[\mathrm{X}] \mathrm{B}] \Rightarrow[[[\mathrm{X}] \mathrm{Y}] \mathrm{B}]$ for all suffixes containing the vowel $\mathrm{Y}$

The uniformity constraint in (5) is trivially satisfied if the suffix vowel of $Y$ is harmonically front or back (i. e. if $Y$ harmonically alternates), since in this case the vowel of the suffix that follows $\mathrm{Y}$ has to agree with $\mathrm{Y}$ in backness/frontness: $[[[\mathrm{X}] \mathrm{F}] \mathrm{F}]$ and $[[[\mathrm{X}] \mathrm{B}] \mathrm{B}]$ since $*[[[\mathrm{X}] \mathrm{F}] \mathrm{B}]$ and $*[[[\mathrm{X}] \mathrm{B}] \mathrm{F}]$ are harmonically ill-formed. The only case where constraint (5) does take a real effect is when the suffix vowel of $\mathrm{Y}$ is neutral (and Y is invariant), $\mathrm{i}$. e. when the vowel is /i/, /i:/ or /e:/. ${ }^{5}$ In our case, monosyllabic all-neutral roots can be lexically harmonic [[N]F] or anti-harmonic [[N]B]. Due to (5) this distinction will be preserved when the root is suffixed with an invariant suffix that has neutral vowel: $[[[\mathrm{N}] \mathrm{N}] \mathrm{F}]$ and $[[[\mathrm{N}] \mathrm{N}] \mathrm{B}]$. Consider the following examples: hir is harmonically front root (cf. hir-nek /hi:rnek/ 'news-DAT') and sir is anti-harmonic (cf. sir-nak / fi:rnok/ 'tomb-DAT'). When the invariant anaphoric possessive suffix -é /e:/ occurs after these roots, the distinction is preserved in a following, harmonically alternating suffix: hir-é-nekk/*nak /hi:re:nck/ 'news-POSS-DAT') and sir-é-nak/*nek /fi:re:nok/ 'tomb-POSS-DAT'. This latter form / $\mathrm{ji}$ :re:nvk/ shows that the suffixed stem is also anti-harmonic in spite of the fact that it is bisyllabic (compare (4)). This is systematic: other stems and suffixes behave in the same way, (even when he monosyllabic root is bound): e.g. béke, bék-ül - bék-it-hêt/*hat/be:ke, be:kyl - be:ki:thet 'peace, reconcile - make peace-MOD' vs. béna, bén-ul - bén-it-hat ${ }^{*}$ het /be:nv, be:nul - be:ni:thnt-'paralysed, become paralysed - paralyse-MOD' (for a detailed analysis see Rebrus \& Szigetvári 2013).

Harmonic uniformity is also applicable to stems that contain more than one invariant neutral-vowel suffix: in this way anti-harmony can also take place after stems longer than two syllables. This successive suffixation with invariant suffixes can create anti-harmonic stems with sequences of three, four or even more neutral vowels in the stem: the harmonic class of these multiply suffixed stems is always identical with that of the root. This is exemplified in (6) below with 'harmonic' and anti-harmonic roots with two different series of neutral vowel suffixes attached to each root.

The consequence of (5) for all-neutral vowel stems is that polymorphemic anti-harmonic stems can be polysyllabic. Harmonic Uniformity (5) is more dominant than the Polysyllabic Split, the general (phonotactic) constraint on the harmonic properties of all-neutral stems according to which monosyllabic stems can be antiharmonic, but polysyllabic ones cannot (the interaction of HU and harmonic transparency will be discussed in the next section). ${ }^{6}$

The table in (6) summarizes the interaction of Harmonic Uniformity and the Polysyllabic Split. The rows show stems arranged according to morphological complexity: from monomorphemic roots to stems with up to four invariant suffixes containing the neutral vowels /i/, /i:/ or /e:/; the columns show the number of syllables that an allneutral stem contains (for stems of 1 to 6 neutral vowels). F and B identify the harmonic class of the relevant stem (or, equivalently, the harmonic values that a harmonically alternating suffix must take after the relevant type of stem), B|F marks lexical variation.

In the first row, we can see that the harmonic pattern of monomorphemic forms is governed by the Polysyllabic Split: monosyllabic roots can be anti-harmonic (lexical variation), and polysyllabic ones cannot - thus the sequence of harmonic values is the following: (B|F F F F --$)^{7}$ In the second row, the singly suffixed forms follow the same pattern but it is shifted one cell to the right since there are no suffixed forms with vowelless roots, and thus it is impossible for the first cell to contain forms (this is indicated by the mark $X$ ). The second cell in this row contains harmonic and anti-harmonic forms (lexical variation) because of Harmonic Uniformity, thus it is harmonically

$5 / \varepsilon /$ only marginally occurs in invariant suffixes in special diminutive forms which do not play a role here.

6 Harmonic Uniformity (5), however, is not ubiquitous, there are two cases where it is systematically violated: (i) roots suffixed with diminutive suffixes containing the vowel /i/ do not preserve the harmonic class of the original anti-harmonic root stem, (see Törkenczy, Rebrus \& Szigetvári (2013), Rebrus \& Szigetvári 2013), and (ii) alternating suffixes do not preserve the harmonic class of the root, but require the following suffix to be front even if they contain neutral /i/ or /e:/ - see Törkenczy 2011, Törkenczy 2010. In this paper we will not consider these effects.

7 Examples: ind-ul 'start' | disz-ük 'their ornament', idill-nek 'idyll-DAT', ribizli-nek 'currant-DAT', rizibizi-nek 'rise and peasDAT', divizibilis-nek 'divisible-DAT'. The longest occurring monomorphemic all-neutral root in our database has five syllables, therefore the last cell is empty and marked with "-". 
identical to the first cell of the previous row. The rest of the cells in the row only contain harmonically front stems (these are the suffixed forms which have two, three, four and five-syllable roots). Thus, the pattern in the second row is (X B $\mid \mathrm{F} \mathrm{F} \mathrm{F} \mathrm{F} \mathrm{-).}{ }^{8}$ The third row (doubly suffixed forms) is again a right-shifted version of the previous one: mono, or bisyllabic forms that would fit into the first two cells do not exist (for the same reason as above), lexical variation only occurs with three syllables (because the roots of these stems are necessarily monosyllabic), and stems with more than three syllables are obligatorily front harmonic; this yields the following series: (X X B|F F F F). ${ }^{9}$ As we proceed down the table, the same right-shift of the pattern repeats itself. Triply and quadruply suffixed forms have these patterns: (X X X B|F F F), (X X X X B|F F). ${ }^{10}$

(6) Interaction between Harmonic Uniformity and the Polysyllabic Split

\begin{tabular}{|c|c|c|c|c|c|c|}
\hline $\begin{array}{l}\text { number of } \mathrm{N}: \\
\text { stem morphology: }\end{array}$ & $\mathrm{N}$ & $\mathrm{NN}_{-}$ & $\mathrm{NNN}_{-}$ & $\mathrm{NNNN}_{-}$ & NNNNN_ & $\mathrm{NNNNNN}_{2}$ \\
\hline $\begin{array}{l}\text { monomorphemic } \\
\operatorname{root}[\ldots]_{-}\end{array}$ & \begin{tabular}{|c|}
$\mathbf{B} \mid \mathbf{F}$ \\
ind- | dísz
\end{tabular} & $\begin{array}{c}\mathbf{F} \\
\text { idill }\end{array}$ & $\underset{\text { ribizli }}{\mathbf{F}}$ & $\underset{\text { rizibizi }}{\mathbf{F}}$ & $\underset{\text { divizibilis }}{\mathbf{F}}$ & - \\
\hline $\begin{array}{l}\text { singly suffixed stem } \\
{[[\ldots] \mathrm{N}]_{-}}\end{array}$ & $X$ & \begin{tabular}{|c|}
$\mathbf{B} \mid \mathbf{F}$ \\
ind-ít $\mid$ \\
dísz-ít
\end{tabular} & $\underset{\text { idill-i }}{\mathbf{F}}$ & $\underset{\text { ribizli-nyi }}{\mathbf{F}}$ & $\underset{\text { rizibizi-é }}{\mathbf{F}}$ & $\begin{array}{c}\mathbf{F} \\
\text { divizibilis-é }\end{array}$ \\
\hline $\begin{array}{l}\text { doubly suffixed stem } \\
{[[[\ldots] \mathrm{N}] \mathrm{N}]_{-}}\end{array}$ & X & X & \begin{tabular}{|c|}
$\mathbf{B} \mid \mathbf{F}$ \\
ind-ít-ék| \\
dísz-ít-ék \\
\end{tabular} & $\underset{\text { idill-i-é }}{\mathbf{F}}$ & $\frac{\mathbf{F}}{\text { ribizli-nyi-é }}$ & $\underset{\text { rizibizi-é-i }}{\mathbf{F}}$ \\
\hline $\begin{array}{l}\text { triply suffixed stem } \\
{[[[[\ldots] N] N] N]_{-}}\end{array}$ & X & $X$ & $X$ & \begin{tabular}{|c|}
$\mathbf{B} \mid \mathbf{F}$ \\
ind-ít-ék-é| \\
dísz-ít-ék-é
\end{tabular} & $\begin{array}{c}\mathbf{F} \\
\text { idill-i-é-i }\end{array}$ & $\underset{\text { ribizli-nyi-é-i }}{\mathbf{F}}$ \\
\hline $\begin{array}{l}\text { quadruply sfxed stem } \\
{[[[[[\ldots] N] N] N] N]_{-}}\end{array}$ & $X$ & $X$ & $X$ & $\mathrm{X}$ & \begin{tabular}{|c|}
$\mathbf{B} \mid \mathbf{F}$ \\
ind-ít-ék-é-i| \\
dísz-ít-ék-é-i
\end{tabular} & $\underset{\text { idill-i-é-i-é }}{\mathbf{F}}$ \\
\hline
\end{tabular}

The complexity of (6) resulting from the interaction of Harmonic Uniformity and the Polysyllabic Split has striking consequences for the harmonic patterns. Since all the rows (harmony (sub)types) have different patterns, and every column (harmonic context) differs at some point from every other column in the harmonic values it assigns, no types and no contexts can be merged without loss of information. Thus, both the harmony types (patterns) and the harmonic contexts proliferate. The polysyllabic harmonic context $\left[\mathrm{NN}^{+}\right]$introduced in (4) has to be split into [NN], [NNN], [NNNN] and so forth-according to the number of the syllables of the (monomorphemic or polymorphemic) stem. In order to capture the Hungarian harmony system, we need all the harmonic contexts of (6) separately, and we need all the different subtypes too: the monomorphemic type (4) has to be supplemented with new types which differ in the number of N-suffixes in the stem.

In the next section we will examine the second kind of variable harmonic pattern: the variable transparency of neutral vowel sequences in Hungarian (vacillation).

2.2 Variation in transparency It is well-known (e.g. Vago 1980, Siptár and Törkenczy 2000) that in Hungarian disharmonic mixed roots containing a (series of) back vowel(s) and one neutral vowel (BN]_) count as harmonically back. This transparent behaviour is virtually invariable in the case of $/ \mathrm{i}, \mathrm{i}: /$ and shows a very little variability in the

8 Examples: ind-it-va 'start-TRANS-PART' | disz-it-ve 'decorate-PART', idill-i-nek 'idyllic-DAT', ribizli-nyi-nek 'currantfulDAT', rizibizi-é-nek 'rise and peas-POSS-DAT', divizibilis-é-nek 'divisible-POSS-DAT'.

9 Examples: ind-it-ék-nak 'motive-DAT' | dísz-it-ék-nek 'decoration-DAT', idill-i-é-nek 'idyllic-POSS-DAT', ribizli-nyi-é-nek 'currantful-POSS-DAT', rizibizi-é-i-nek 'rise and peas-POSS-PL-DAT'.

10 Examples: ind-it-ék-é(-i)-nak 'motive-POSS(-PL)-DAT' | dísz-it-ék-é(-i)-nek 'decoration-POSS(-PL)-DAT', idill-i-é-i-(-é)nek 'idyllic-POSS-PL(-POSS)-DAT', ribizli-nyi-é-i-nek 'currantful-POSS-PL-DAT'. 
case of /e:/. If, however, the root contains more than one of these final neutral vowels ( $\left.\left.\mathrm{BN}^{+}\right]_{\_}\right)$, then massive variability occurs, which is manifested in a high degree of vacillation (intraspeaker variation) after the root type [Bi(:)i(:)] (e.g. alibi-val/-vel 'with alibi'), [Bi(:)e:] (e.g. klarinét-nak/-nek 'clarinet-DAT') and [Be:i(:)] (e.g. protézis$e k /-o k$ 'denture-PLUR'). ${ }^{11}$ This phenomenon, that the transparency/opacity of neutral vowel(s) is quantitatively sensitive is the Count Effect, see Hayes \& Cziráky Londe 2006. The Count Effect has a consequence for the harmonic pattern: the original subsumption of contexts we labeled $\mathrm{BN}$ ] as in (3) and (4) has to be split into [BN] containing exactly one $\mathrm{N}$ and $\mathrm{BNN}^{+}$] containing more than one. This is shown in (7) below (where the monosyllabic neutral context $[\mathrm{N}]$ is omitted for the sake of simplicity). The table (7) shows that the behaviour of [BN]-stems and $\mathrm{BNN}^{+}$]-stems differ, i. e. Hungarian displays the Count Effect and variation in transparency simultaneously.

(7) The Count Effect: variation in transparency after multiple N's

\begin{tabular}{|l|c|c|c|c|c|c|}
\hline stem contexts: & {$[\mathrm{B}]_{-}$} & {$[\mathrm{BN}]_{-}$} & {$\left[\mathrm{BNN}^{+}\right]_{-}\left[\mathrm{NN}^{+}\right]_{-}$} & {$[\mathrm{FN}]_{-}$} & {$[\mathrm{F}]_{-}$} \\
\hline transparent, Count Effect and variation & $B$ & $B$ & $\boldsymbol{B} \% \boldsymbol{F}$ & $F$ & $F$ & $F$ \\
\hline
\end{tabular}

Similarly to anti-harmony, the Count Effect and therefore the variation in transparency also interacts with Harmonic Uniformity (5). The relationship is the same as between Harmonic Uniformity and the Polysyllabic Split. Harmonic Uniformity dominates here too: it overrides the Count Effect. This is illustrated in (8) below. A comparison of the columns (i) and (ii) shows that the harmonic class of the root is preserved even when the Count Effect would predict variation. In row (a) we can see that the harmonic class of a [B] stem is preserved even when a neutral suffix follows it. The form in cell (8aiii), which is supplied for comparison, shows that this is not in conflict with the way a [BN] stem behaves when the neutral vowel is part of the root. In row (c) we can see that the harmonic class of the root is preserved even in the case of variation: if there is vacillation after the stem derived by a neutral-vowel suffix. A [BNNN] root (where the third $\mathrm{N}$ is part of the root and not a suffix - see column (iii)) behaves in the same way as a $[[\mathrm{BNN}] \mathrm{N}]$ stem. The crucial case is shown in row (b): here we also find that the harmonic class of the root is preserved (there is no vacillation after a $[\mathrm{BN}]$ stem and after an N-suffix added to a [BN]-stem: compare column (i) with (ii). This, however, is in conflict with the Count Effect, as the form in cell (8biii) shows in which the Count Effect applies and results in vacillation.

(8) Harmonic Uniformity dominates the Count Effect (examples with singly suffixed stems) ${ }^{12}$

\begin{tabular}{|c|c|c|c|c|}
\hline stem type & $\begin{array}{c}\text { (i) harmonic class of } \\
\text { the stem }\end{array}$ & $\begin{array}{l}\text { (ii) harmonic class of } \\
\text { stem }+N \text {-suffix }\end{array}$ & $\begin{array}{l}\text { (iii) harmonic class of } \\
\text { monomorphemic forms }\end{array}$ & stem type \\
\hline a. [B] & $\begin{array}{c}{[\mathrm{B}] \mathbf{B}} \\
\text { ház-nak }\end{array}$ & $\begin{array}{c}=\quad[\mathrm{B}] \mathrm{N}] \mathbf{B} \\
\text { ház-i-nak }\end{array}$ & $\begin{array}{c}{[\mathrm{BN}] \mathbf{B}} \\
\text { vádli-nak }\end{array}$ & {$[\mathrm{BN}]$} \\
\hline b. $[\mathrm{BN}]$ & $\begin{array}{c}{[\mathrm{BN}] \mathbf{B}} \\
\text { madrid-nak }\end{array}$ & $=\underset{\text { madrid-i-nak }}{[[\mathrm{BN}] \mathrm{N}] \mathbf{B}} \neq$ & $\begin{array}{c}{[\mathrm{BNN}] \mathbf{B} \% \mathbf{F}} \\
\text { martini-nak/-nek }\end{array}$ & {$[\mathrm{BNN}]$} \\
\hline c. $[\mathrm{BNN}]$ & $\begin{array}{c}{[\mathrm{BNN}] \mathbf{B} \% \mathbf{F}} \\
\text { martinik-nak/-nek }\end{array}$ & $\begin{array}{c}=[[\mathrm{BNN}] \mathrm{N}] \mathbf{B} \% \mathbf{F}= \\
\text { martinik-i-nak/-nek }\end{array}$ & $\begin{array}{c}{[\mathrm{BNNN}] \mathbf{B} \% \mathbf{F}} \\
\text { horribilis-nak/-nek }\end{array}$ & {$[\mathrm{BNNN}]$} \\
\hline
\end{tabular}

11 Type [Be:e:] is virtually non-existent, the only examples are rare proper names, e.g. Athéné [pte:ne:] 'Athena'. There are very few words with three neutral vowels in this position ([BNNN], e.g. horribilis 'horrible'), and words with more than three are non-existent.

12 Glosses: ház-nak 'house-DAT', ház-i-nak 'domestic-DAT', vádli-nak 'calf-DAT', Madrid-nak 'Madrid-DAT', madrid-i-nak 'Madrid-ADJ-DAT', martini-nak/-nek 'martini-DAT', Martinik-nak/-nek 'Martinique-DAT', martinik-i-nak/-nek 'Martinique-ADJDAT', horribilis-nak/-nek 'horrible-DAT'. 
In (9) we give an overview of the interaction between Harmonic Uniformity and the Count Effect. The table (9) is similar to (6). Here too the rows of the table show stems arranged according to morphological complexity: from monomorphemic roots to stems with up to four suffixes. The columns show the number of neutral-vowel syllables that follow a back-vowel syllable in a stem (from 1 up to 6 neutral vowels). $F$ and $B$ identify the harmonic values that the vowel of a harmonically alternating suffix must have when the suffix occurs after the relevant type of stem. $B \% F$ marks vacillation between the harmonic values that a suffix can take in a given harmonic context. As in (6), cells that cannot have forms are marked with X. Note that the cells that cannot have forms are only 'missing' because we are looking at stems as harmonic contexts that only contain suffixes with invariant neutral vowels: e. g. it is not possible for a context to consist of a stem doubly suffixed with neutral vowel suffixes and to contain a single neutral vowel.

(9) Interaction between Harmonic Uniformity and the Count Effect

\begin{tabular}{|c|c|c|c|c|c|c|}
\hline $\begin{array}{l}\text { number of } \mathrm{N} \text { : } \\
\text { stem morphology: }\end{array}$ & $\mathrm{BN}_{-}$ & $\mathrm{BNN}_{-}$ & BNNN_ & BNNNN_ & BNNNNN_ & BNNNNNN_ \\
\hline $\begin{array}{l}\text { monomorphemic root } \\
{[\ldots]_{-}}\end{array}$ & $\begin{array}{c}\text { B } \\
\text { Madrid }\end{array}$ & $\begin{array}{c}\mathbf{B} \% \mathbf{F} \\
\text { Martinik }\end{array}$ & $\begin{array}{c}\mathbf{B} \% \mathbf{F} \\
\text { horribilis }\end{array}$ & - & - & - \\
\hline $\begin{array}{l}\text { singly suffixed stem } \\
{[[\ldots] \mathrm{N}]_{-}}\end{array}$ & $\begin{array}{c}\text { B } \\
\text { ház-i }\end{array}$ & $\begin{array}{l}\text { B } \\
\text { madrid-i }\end{array}$ & $\begin{array}{c}\mathbf{B} \% \mathbf{F} \\
\text { martinik-i }\end{array}$ & $\begin{array}{c}\mathbf{B} \% \mathbf{F} \\
\text { horribilis-é }\end{array}$ & - & - \\
\hline $\begin{array}{l}\text { doubly suffixed stem } \\
{[[[\ldots] \mathrm{N}] \mathrm{N}]_{-}}\end{array}$ & $X$ & $\begin{array}{c}\text { B } \\
\text { ház-i-é }\end{array}$ & $\begin{array}{c}\text { B } \\
\text { madrid-i-é }\end{array}$ & $\begin{array}{c}\mathbf{B} \% \mathbf{F} \\
\text { martinik-i-é }\end{array}$ & $\begin{array}{c}\mathbf{B} \% \mathbf{F} \\
\text { horribilis-é-i }\end{array}$ & - \\
\hline $\begin{array}{l}\text { triply suffixed stem } \\
{[[[[\ldots] \mathrm{N}] \mathrm{N}] \mathrm{N}]_{-}}\end{array}$ & $X$ & $X$ & $\begin{array}{c}\text { B } \\
\text { ház-i-é-i }\end{array}$ & $\frac{\mathbf{B}}{\text { madrid-i-é-i }}$ & $\begin{array}{c}\mathbf{B} \% \mathbf{F} \\
\text { martinik-i-é-i }\end{array}$ & $\begin{array}{c}\mathbf{B} \% \mathbf{F} \\
\text { horribilis-é-i-é }\end{array}$ \\
\hline $\begin{array}{l}\text { quadruply suffixed stem } \\
{[[[[\ldots] \mathrm{N}] \mathrm{N}] \mathrm{N}]_{-}}\end{array}$ & $X$ & $X$ & $\mathrm{X}$ & $\begin{array}{c}\text { B } \\
\text { ház-i-é-i-é }\end{array}$ & $\begin{array}{c}\text { B } \\
\text { madrid-i-é-i- } \\
\text { é }\end{array}$ & $\begin{array}{c}\mathbf{B} \% \mathbf{F} \\
\text { martinik-i-é-i-é }\end{array}$ \\
\hline
\end{tabular}

The first row shows the Count Effect after monomorphemic $\mathrm{BN}^{+}$] roots: vacillation occurs when there is more than one neutral vowel and there is no vacillation, only back harmony if there is just one: ${ }^{13}$ Madrid-nak/*-nek 'for Madrid', but Martinik-nak/-nek 'for Martinique'. ${ }^{14}$ In the rest of the rows in (9) we can see the same pattern shifted to the right by one cell. This is due to Harmonic Uniformity overriding the Count Effect. For instance, in the second row there is no vacillation after a BNN stem (while in the first one there is) and only a $B$ suffix is possible, because here the morphological structure is $[[\mathrm{BN}] \mathrm{N}]$ and according to Harmonic Uniformity (5), the whole stem inherits the harmonic class of its root [BN], which is B (as shown in the preceding row one cell to the left). This pattern repeats itself as we proceed down the table: variation only occurs after a string of N-syllables if the root already has more than one N-syllable (i. e. Harmonic Uniformity overrides the Count Effect). Even very long strings of N-syllables do not trigger the Count Effect after a $\left[\mathrm{BN}^{+}\right]$stem if the root has only one N-syllable or none: e.g. compare madrid$n a k{ }^{*}$-nek 'Madrid-DAT' and madrid-i-é-i-é-nak/*-nek ,Madrid-ADJ-POSS-PLUR-POSS-DAT'; ház-nak/*-nek 'house-DAT' and ház-i-é-i-é-nak/*-nek 'house-ADJ-POSS-PLUR-POSS-DAT'.

As in the case of anti-harmony, we find that here too there are several 'subtypes' of Hungarian with different harmonic patterns. If we want to capture the Hungarian pattern, we have to decompose the context $\mathrm{BN}]_{-}$of (3) and (4) into the more specific contexts of (9) that it subsumes, just as we had to decompose the context [N] in the the case of anti-harmony. Since (i) the Polysyllabic Split is a kind of count effect that makes a distinction between a single occurrence of an N-syllable vs. multiple occurrences of N-syllables and (ii) both the Polysyllabic Split and the Count Effect are overridden by Harmonic Uniformity, the decomposition of the harmonic contexts $[\mathrm{N}]_{-}$and [BN]_

13 Disregarding the Height Effect.

14 There are no $\left[\mathrm{BN}^{+}\right]$roots with more than three Ns hence the cells marked '-'. 
results in coherent subtypes in Hungarian, i. e. the combination of the two phenomena does not increase the number of subtypes/subpatterns even though the number of harmonic contexts (points in the frontness/backness scale) has increased.

We demonstrate this in table (10), which gives an overview of the harmonic patterns of stems whose final syllable is an N-syllable by combining the decomposed harmonic contexts for transparency and anti-harmony.

(10) Harmonic behaviour of neutral-final stems

\begin{tabular}{|c|c|c|c|c|c|c|c|c|c|c|}
\hline $\begin{array}{r}\text { stem contexts } \\
\text { stem morphology }\end{array}$ & $\mathrm{B}^{+} \mathrm{N}_{-}$ & $\mathrm{B}^{+} \mathrm{NN}_{-}$ & $\mathrm{B}^{+} \mathrm{NNN}_{-}$ & $\ldots$ & $\mathrm{N}_{-}$ & $\mathrm{NN}_{-}$ & $\mathrm{NNN}_{-}$ & $\mathrm{NNNN}_{-}$ & ... & $\mathrm{F}^{+} \mathrm{N}_{-}^{+}$ \\
\hline $\begin{array}{l}\text { monomorphemic } \\
\text { stem }[\ldots \mathrm{N}]_{-}\end{array}$ & $\begin{array}{c}{[\mathrm{BN}]} \\
\boldsymbol{B}\end{array}$ & $\begin{array}{l}{[\mathrm{BNN}]} \\
\boldsymbol{B} \% \boldsymbol{F}\end{array}$ & $\begin{array}{c}{[\mathrm{BNNN}]} \\
\boldsymbol{B} \% \boldsymbol{F}\end{array}$ & $\cdots$ & $\begin{array}{l}{[\mathrm{N}]} \\
\boldsymbol{B} \mid \boldsymbol{F}\end{array}$ & $\begin{array}{c}{[\mathrm{NN}]} \\
\boldsymbol{F}\end{array}$ & $\begin{array}{c}{[\mathrm{NNN}]} \\
\boldsymbol{F}\end{array}$ & $\begin{array}{c}{[\mathrm{NNNN}]} \\
\boldsymbol{F}\end{array}$ & $\cdots$ & $\begin{array}{c}{[\mathrm{F}(\mathrm{N}) \mathrm{N}]} \\
\boldsymbol{F}\end{array}$ \\
\hline $\begin{array}{l}\text { singly suffixed } \\
\text { stem }[[\ldots] N]_{-}\end{array}$ & $\frac{[[\mathrm{B}] \mathrm{N}]}{\boldsymbol{B}}$ & $\begin{array}{c}{[[\mathrm{BN}] \mathrm{N}]} \\
\boldsymbol{B}\end{array}$ & $\begin{array}{c}{[[\mathrm{BNN}] \mathrm{N}]} \\
\boldsymbol{B} \% \boldsymbol{F}\end{array}$ & $\ldots$ & $\mathrm{X}$ & $\begin{array}{c}{[[\mathrm{N}] \mathrm{N}]} \\
\boldsymbol{B} \mid \boldsymbol{F}\end{array}$ & $\begin{array}{c}{[[\mathrm{NN}] \mathrm{N}]} \\
\boldsymbol{F}\end{array}$ & $\begin{array}{c}[\mathrm{NNN}] \mathrm{N}] \\
\boldsymbol{F}\end{array}$ & $\cdots$ & $\begin{array}{c}{[[\mathrm{FN}] \mathrm{N}]} \\
\boldsymbol{F}\end{array}$ \\
\hline $\begin{array}{l}\text { doubly sfxed } \\
\text { stem }[[[\ldots] \ldots] N]\end{array}$ & $\begin{array}{c}{[[[\mathrm{B}] \mathrm{B}] \mathrm{N}]} \\
\boldsymbol{B}\end{array}$ & $\begin{array}{c}{[[[\mathrm{B}] \mathrm{N}] \mathrm{N}]} \\
\boldsymbol{B}\end{array}$ & $\left|\begin{array}{c}{[[[\mathrm{BN}] \mathrm{N}] \mathrm{N}]} \\
\boldsymbol{B}\end{array}\right|$ & $\ldots$ & $X$ & $X$ & $\begin{array}{c}{[[[\mathrm{N}] \mathrm{N}] \mathrm{N}]} \\
\quad \boldsymbol{B} \mid \boldsymbol{F}\end{array}$ & {$\left[\begin{array}{c}{[[[\mathrm{NN}] \mathrm{N}] \mathrm{N}]} \\
\boldsymbol{F}\end{array}\right.$} & $\cdots$ & $\begin{array}{c}{[[[\mathrm{FN}] \mathrm{N}] \mathrm{N}]} \\
\boldsymbol{F}\end{array}$ \\
\hline $\begin{array}{l}\text { triply sfxed stem } \\
{[[[[\ldots] \ldots] \ldots] N]_{-}}\end{array}$ & $\begin{array}{c}{[[[[\mathrm{B}] \mathrm{B}] \mathrm{B}] \mathrm{N}]} \\
\boldsymbol{B}\end{array}$ & $\begin{array}{c}{[[[[\mathrm{B}] \mathrm{B}] \mathrm{N}] \mathrm{N}]} \\
\boldsymbol{B}\end{array}$ & $\left|\begin{array}{c}{[[[[\mathrm{B}] \mathrm{N}] \mathrm{N}] \mathrm{N}]} \\
\boldsymbol{B}\end{array}\right|$ & $\ldots$ & $X$ & $\mathrm{X}$ & $X$ & $\begin{array}{c}{[[[[\mathrm{N}] \mathrm{N}] \mathrm{N}] \mathrm{N}]} \\
\boldsymbol{B} \mid \boldsymbol{F}\end{array}$ & $\ldots$ & $\begin{array}{c}{[[[\mathrm{FN}] \mathrm{N}] \mathrm{N}]} \\
\boldsymbol{F}\end{array}$ \\
\hline & $\cdots$ & $\ldots$ & $\ldots$ & $\ldots$ & & & & & & $\ldots$ \\
\hline
\end{tabular}

Table (10) combines the information in table (6) and (9): it contains the subcontexts that result from the decomposition of the general all-neutral context $\left[\mathrm{N}^{+}\right]_{-}$and the subcontexts that result from the decomposition of the general $[\mathrm{BN}]_{-}\left(=\left[\mathrm{B}^{+} \mathrm{N}^{+}\right]_{-}\right)$harmonic context. ${ }^{15}$ We can see that these two decompositions result in the same subtypes, the same co-phonologies of the general Hungarian pattern (variably transparent, variably anti-harmonic).

\section{Monotonicity}

3.1 Monotonicity of the Hungarian pattern The Hungarian pattern is monotonic even when variation in transparency and in anti-harmony have been included. This is because in any subpattern, variation, i. e. the harmonic value $B / F$ (vacillation or lexical variation), may occur in one or more harmonic contexts that are contiguous in the backness/frontness scale while the values assigned to all the contexts before the first context with variation are $B$ and the values assigned to all the contexts after the last context with variation are $F$, see Rebrus and Törkenczy, to appear. $^{16}$

In what follows we take a closer look at the monotonicity of the patterns in (10). The picture we see in (10), which distinguishes many subtypes according to fine distinctions in the morphological and phonological complexity of contexts is not quite suitable (i) theoretically and (ii) empirically. (i) There is no non-arbitrary limit in the number of contexts and subpatterns that can be distinguished in principle (this is indicated by the ellypsis points in (10)). (ii) The type and token frequency of forms dramatically reduces as the morphology becomes more and more complex or the number of neutral vowels increase and therefore quantified data about harmony in morphologically and phonologically more complex contexts becomes less and less reliable. Therefore, it is reasonable to simplify (10) by

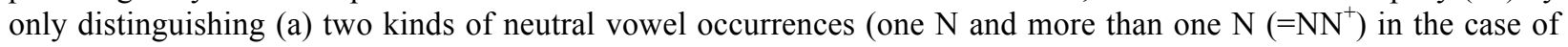

15 The two prototypical contexts $\mathrm{B}_{-}^{+}$and $\mathrm{F}_{-}^{+}$are left out since they are not $\mathrm{N}$-final. Note that the empty cells of Table (9) have been 'filled': in (10) only the last suffix of a harmonic context has to be an N-suffix, so e. g. a doubly suffixed context with a single final $\mathrm{N}$ can exist if the first suffix has a harmonic vowel (B in the case of the cell in row three column one). The empty cells of (9) have been filled in with B in (10) because of Harmonic Uniformity (the roots of the relevant stems are always [B]).

16 This is true of all the harmonic contexts that can be assigned a harmonic value of all subpatterns: 'empty cells' do not influence the monotonicity of a pattern. 
all-neutral stems (fourth and fifth column in (11) below) and in the case of disharmonic stems (second and third column in (11) below), and (b) two degrees of morphological complexity (monomorphemic and suffixed) in harmonic contexts (first and second row). This gives us a seven point-scale of harmonic contexts and two subtypes of patterns as shown in (11i,ii).

(11) Variable patterns: two subtypes, seven contexts

\begin{tabular}{|l|c|c|c|c|c|c|c|}
\hline $\begin{array}{c}\text { stem context: } \\
\text { stem morphology: }\end{array}$ & $\mathrm{B}_{-}^{+}$ & $\mathrm{B}^{+} \mathrm{N}_{-}$ & $\mathrm{B}^{+} \mathrm{NN}_{-}^{+}$ & $\mathrm{N}_{-}$ & $\mathrm{NN}_{-}^{+}$ & $\mathrm{F}^{+} \mathrm{N}^{+}$ & $\mathrm{F}^{+}$ \\
\hline i. monomorphemic & $B$ & $\boldsymbol{B}$ & $\boldsymbol{B} / \boldsymbol{F}$ & $\boldsymbol{B} / \boldsymbol{F}$ & $\boldsymbol{F}$ & $F$ & $F$ \\
\hline ii. suffixed & $B$ & $\boldsymbol{B}$ & $\boldsymbol{B} / \boldsymbol{F}$ & $\mathrm{X}$ & $\boldsymbol{B} / \boldsymbol{F}$ & $F$ & $F$ \\
\hline iii. overall & $B$ & $\boldsymbol{B}$ & $\boldsymbol{B} / \boldsymbol{F}$ & $\boldsymbol{B} / \boldsymbol{F}$ & $\boldsymbol{B} / \boldsymbol{F}$ & $F$ & $F$ \\
\hline
\end{tabular}

It can be seen from (10) above that both the Count Effect and the Polysyllabic Split are in operation: the former manifests itself in the difference between the values in the second and the third column (contexts $\mathrm{B}^{+} \mathrm{N}_{-}$vs. $\mathrm{B}^{+} \mathrm{NN}_{-}^{+}$), and the latter in the difference between the values in the fourth and the sixth column (contexts $\mathrm{N}_{-}^{-}$vs. $\mathrm{NN}^{+}$, where the difference only shows up in monomorphemic forms (first row)). The last row shows the overall pattern which merges the monomorphemic and the polymorphemic cases - the result is the seven-member pattern with three variation sites. ${ }^{17}$ All the patterns (11i-iii) are monotonic since the harmonic values in them are contiguous they appear in a proper order from $B$ to $F$.

3.2 Quantification and corpus study We wanted to examine the monotonicity of these patterns as manifested in frequency. Therefore we have carried out a corpus study to discover the "frontness ratio" of variable sites, i. e. the relative token frequencies of forms suffixed by the front alternant in a given type of context. We used the Hungarian webcorpus Szószablya (Halácsy et al. 2004, Szószablya 2014), which contains about 541 million tokens of words. The following table in (12) shows the results, where the frontness is set in large bold-face, and the numbers of all harmonically suffixed forms (in thousands of tokens) are given in subscript. Table (12) contains data only about forms with neutral the vowels /i/ or /i:/. The suffixes in the forms counted are always inflectional, because inflectional forms can be obtained from the corpus we used with higher reliability. The set-up of the table (12) follows the set-up of the table (11), and contains quantified information about the same harmonic patterns.

(12) The 'frontness ratios' of harmonically suffixed forms by token frequency $(\mathrm{N}=\mathrm{i} / \mathrm{i}$;, only inflections)

\begin{tabular}{|c|c|c|c|c|c|c|c|}
\hline $\begin{array}{l}\text { stem context: } \\
\text { stem morphology: }\end{array}$ & $\mathrm{B}_{-}^{+}$ & $\mathrm{BN}_{-}$ & $\mathrm{BNN}_{-}^{+}$ & $\mathrm{N}_{-}$ & $\mathrm{NN}^{+}$ & $\mathrm{F}^{+} \mathrm{N}^{+}$ & $\mathrm{F}^{+}$ \\
\hline i. monomorphemic & 0 & $\mathbf{0}_{642}$ & $\mathbf{0 . 0 8}_{33}$ & $\mathbf{0 . 7 0}_{3082}$ & $\mathbf{1}_{69}$ & 1 & 1 \\
\hline ii. suffixed & 0 & $\mathbf{0}_{62}$ & $\mathbf{0}_{0.5}$ & $\mathrm{X}$ & $0.43_{8}$ & 1 & 1 \\
\hline iii. overall & 0 & $\mathbf{0}$ & 0.08 & 0.70 & 0.93 & 1 & 1 \\
\hline
\end{tabular}

17 As mentioned before, there is a small degree of variation in the case of $\mathrm{B}^{+} \mathrm{N}$-stems (second column), but if the neutral vowel $(\mathrm{N})$ is $\mathrm{i} / \mathrm{i}$ : this variability is negligible. 
It can be seen from (12) that the suffixed pattern (2nd row) is more disharmonic than the monomorphemic pattern (1st row) since the numbers in the relevant cells are smaller (which means that the relative frequency of $B$-suffixed tokens is higher, which is disharmony in the relevant contexts). This is the effect of Harmonic Uniformity (5) overriding the Count Effect and the Polysyllabic Split - the numbers in (12) show the same 'right-shift' we found in (10). Note that in the case of the context $\mathrm{BNN}^{+}$(2nd row, 3rd column) the number 0 (i. e. non-variable back behaviour) occurs in the cell instead of the expected variable behaviour (compare the same cell in (11)). We attribute this to Harmonic Uniformity: very few forms belong here (0.5 thousand tokens) and a vast majority of the tokens that do have stems of the type $[[\mathrm{BN}] \mathrm{N}]$ or $[[[\mathrm{B}] \mathrm{N}] \mathrm{N}]$ (and not $\left[\left[\mathrm{BNN}^{+}\right] \mathrm{N}\right]$ ). As Harmonic Uniformity requires that the harmonic class of the root should be preserved, we get invariant back suffix harmony (0) instead of variation.

The difference between monomorphemic and polymorphemic forms is also significant in the case of the allneutral stems (context $\mathrm{NN}^{+}$; 5th column): the monomorphemic case is non-variable front (because of the Polysyllabic Split), and a high degree of variation occurs among the polymorphemic stems (as the number 0.43 shows). The variation attested is partly due to Harmonic Uniformity too: many tokens that belong here have monosyllabic roots (i. e. the relevant stems are $[[\mathrm{N}] \mathrm{N}]$ and not $\left[\left[\mathrm{NN}^{+}\right] \mathrm{N}\right]$ ) and monosyllabic neutral roots show a high degree of variation (as shown by the number 0.70, see column 4, row 1), which these stems are required to preserve.

It must be noted that even in the monomorphemic case (when Harmonic Uniformity can have no influence), the Count Effect only has a statistically small impact on the token frequencies given here (as shown by the number 0.08, see column 3, row 1): the cumulative ratio of front suffixed tokens of $\mathrm{BNN}^{+}$-stems is only $8 \%$, i. e. there $i s$ variation, but there is a strong preference for back harmony. ${ }^{18}$ By contrast, the Polysyllabic Split has a striking effect on token frequencies: compare 0.70 and 1 in the contexts $\mathrm{N}$ and $\mathrm{NN}^{+}$, respectively (1st row, 4th and 5 th cells).

In a quantified model (see Rebrus and Törkenczy 2014b and Rebrus and Törkenczy to appear) monotonicity means that the series of values assigned to the harmonic contexts must (non-strictly) increase in accordance with the ordering of contexts. If the assignment function of a pattern satisfies this requirement, then it is monotonic and therefore well-formed.

Despite the complexities of variation discussed above and the great differences between the number of tokens in the various harmonic contexts, all the patterns in (12) (the subpatterns and the overall pattern, which merge some contexts of the subpatterns) are monotonic in this sense. Thus, in these patterns (i) the occurrence of variation (i.e. the position of the contexts with variable values relative to the invariable contexts) is appropriate and (ii) the complete series of values is increasing in accordance with the ordering of contexts.

The quantified model makes it possible to make fine-grained predictions about well-formed harmonic patterns. For instance monotonicity in a quantified model predicts that in a possible harmony system that has variable transparency and variable anti-harmony, the effect of anti-harmony must be weaker than the effect of transparency, i. e. the ratio of back suffix alternants in the context of $[\mathrm{N}]_{-}$should be lower that in the contexts of $[\mathrm{BN}]_{-}$and $\left[\mathrm{BNN}^{+}\right]_{-}$. Consider the variation sites $\mathrm{BNN}_{-}^{+}$and $\mathrm{N}_{-}$in the monomorphemic Hungarian pattern in (12i). The first site is subject to the Count Effect (which disfavours transparency to a small degree), but nevertheless transparency is still stronger than anti-harmony (the relative token frequency of forms with a front suffix alternant is lower in the case of transparency than in anti-harmony, $p_{1}=0.08, p_{2}=0.70$ ) -- as monotonicity requires in this quantified model. This model then predicts a correspondence between the Count Effect and the effect of anti-harmony: assuming a given degree of variation in anti-harmony, the Count Effect cannot be strong enough to suppress transparency to a degree $\left(p_{1}\right)$ which is greater than the harmonic effect in anti-harmony $\left(p_{2}\right) .{ }^{19}$

Another prediction that can be made is about variation sites "sandwiched" between variation sites because according to monotonicity the value assigned to a variation site flanked by other variation sites must be between the values assigned to the flanking sites. The overall pattern in (12iii) has this property, since there is a sandwiched

18 Interestingly, this is in disagreement with descriptive statements about variation in Hungarian harmony in the literature (see Törkenczy 2011 for an overview).

19 There are approaches to the Count Effect in Hungarian which try to explain the variation in context $\mathrm{BNN}_{-}^{+}$as the coexistence of two invariable patterns one of which has a Count Effect so strong that it results in total opacity after more than one N (e.g. Nevins 2010). Our analysis predicts that, assuming the existence of (some degree of) anti-harmony in the same pattern, such a pattern cannot be a well-formed (monotonic) subpattern. 
variation site in it and the series of relevant values is $\langle\ldots, 0.08,0.70,0.93, \ldots\rangle$. The relationship between the first two variation sites is the same as the one we discussed above (Count Effect vs. anti-harmony). The relationship between the second and the third variation sites can be explained with reference to the relationship between Harmonic Uniformity and the Polysyllabic Split. The occurrence of variation in the third variation site is due to Harmonic Uniformity preserving the harmonic class of monosyllabic anti-harmonic stems $[\mathrm{N}]$ (and also the harmonic class of monosyllabic non-anti-harmonic stems) in the context $\left[[\mathrm{N}] \mathrm{N}^{+}\right]$. In addition, monomorphemic $\left[\mathrm{NN}^{+}\right]$stems also belong here, which are subject to the Polysyllabic Split (requiring front harmony). Thus, these two requirements have opposite effects in this context: the Polysyllabic Split increases the value and Harmonic Uniformity decreases it. The quantified model predicts the following: the anti-harmonicity that Harmonic Uniformity preserves, i. e. carries over from monosyllabic anti-harmonic stems, cannot be stronger than the effect of the Polysyllabic Split (expressed in the token frequencies of forms under the purview of these two constraints).

\section{References}

Blaho, Sylvia \& Dániel Szeredi. 2013. Hungarian neutral vowels: A microcomparison. Nordlyd 40(1). 20-40. http://septentrio.uit.no/index.php/nordlyd/article/view/2499 (accessed 14 February 2015).

Coetzee, Andries W. \& Joe Pater. 2011. The place of variation in phonological theory. In J Goldsmith, J Riggle \& A Yu (eds.), The Handbook of Phonological Theory. 2nd Edition, 401-434. Oxford: Blackwell.

Forró, Orsolya. 2013. Ingadozás a magyar elölségi harmóniában. Szempontok a variabilitás szinkróniájának és diakróniájának feltárásához és értelmezéséhez [Variation in palatal harmony in Hungarian. Approaches to the interpretation of synchronic and diachronic variability]. Piliscsaba: Pázmány Péter Katolikus Egyetem $\mathrm{PhD}$ dissertation.

Halácsy, Péter, András Kornai, László Németh, András Rung, István Szakadát, and Viktor Trón (2004). Creating open language resources for Hungarian In Proceedings of Language Resources and Evaluation Conference (LREC04), 203-210. LREC.

Hayes, Bruce and Zsuzsa Cziráky Londe. 2006. Stochastic phonological knowledge: The case of Hungarian vowel harmony. Phonology 23. 59-104.

Kálmán, László, Péter Rebrus \& Miklós Törkenczy. 2012. Possible and impossible variation. In F Kiefer, M Ladányi \& P Siptár (eds.), Current Issues in Morphological Theory. (Ir)regularity, Analogy and Frequency. Papers from the 14th International Morphology Meeting, Budapest, 13-16 May 2010, 23-49. Amsterdam/Philadelphia: John Benjamins.

Kiparsky, Paul \& Karl Pajusalu. 2003. Towards a typology of disharmony. The Linguistic Review 20. $217-241$.

Kis, Tamás. 2005. A veláris $i$ a magyarban [Back $i$ in Hungarian]. Magyar Nyelvjárások 43. 5-26.

Nevins, Andrew. 2010. Locality in Vowel Harmony. Cambridge, Mass: MIT Press.

Rebrus, Péter, Péter Szigetvári. (2013). Antiharmony, transparency, truncation. Poster presented at the 21st Manchester Phonology Meeting, 25 May 2013. http://seas3.elte.hu/szigetva/papers/att.pdf (accessed 14 February 2015)

Rebrus, Péter \& Miklós Törkenczy. 2005. Uniformity and contrast in the Hungarian verbal paradigm. In L J Downing, T. A. Hall \& R Raffelsiefen (eds.), Paradigms in phonological theory, 263-295. Oxford: Oxford University Press.

Rebrus, Péter \& Miklós Törkenczy. 2011. Paradigmatic Variation in Hungarian. In T Laczkó \& C Ringen (ed.), Approaches to Hungarian. Papers from the 2009 Debrecen Conference Volume 12., 135-161. Amsterdam/Philadelphia: John Benjamins.

Rebrus, Péter \& Miklós Törkenczy. 2013. Hungarian vowel harmony and the typology of front/back harmony. Paper presented at the 11th International Conference on the Structure of Hungarian (ICSH11), Pázmány Péter Catholic University, Piliscsaba, Hungary, 29-31 August. [http://budling.nytud.hu/ tork/owncikk/icsh2013_prez.pdf] (accessed 14 February 2015)

Rebrus, Péter \& Miklós Törkenczy. 2014a. Monotonicity and the typology of front/back harmony systems. Poster presented at Eleventh Old World Conference in Phonology (OCP11), Leiden University Centre for Linguistics (LUCL) and the Meertens Instituut Amsterdam, Leiden/Amsterdam, The Netherlands 22-25 January [http://budling.nytud.hu/ tork/owncikk/Rebrus\&Torkenczy_monotonicity_poster_OCP11.pdf]

Rebrus, Péter \& Miklós Törkenczy. 2014b. Monotonicity and the limits of disharmony. Poster presented at Phonology 2014, Massachusetts Institute of Technology, Cambridge MA 19-21 September [http://budling.nytud.hu/ tork/owncikk/MIT_2014_poster_5hasab.pdf]

Rebrus, Péter \& Miklós Törkenczy. 2015. Variation and subpatterns of disharmony in Hungarian. Poster presented at the 12th Old World Conference in Phonology (OCP12), Barcelona, 27-30 January.

[http://budling.nytud.hu/ tork/owncikk/OCP_2015_poster_3hasab.pdf). (accessed 14 February 2015]

Rebrus, Péter \& Miklós Törkenczy. to appear. Monotonicity and the typology of front/back harmony. Theoretical Linguistics. 
Rebrus, Péter, Péter Szigetvári \& Miklós Törkenczy. 2012. Dark secrets of Hungarian vowel harmony. In E Cyran, H Kardela \& B Szymanek (eds.), Sound, Structure and Sense: Studies in memory of Edmund Gussmann, 491-508. Lublin: Wydawnictwo KUL.

Ringen, Catherine \& Miklós Kontra. 1989. Hungarian neutral vowels. Lingua 78. 181-191.

Siptár, Péter \& Miklós Törkenczy. 2000. The phonology of Hungarian. Oxford: Oxford University Press.

Szószablya Webcorpus v0.9. 2014) [http://szotar.mokk.bme.hu/szoszablya/searchq.php]

Törkenczy, Miklós. 2010. Invariancia, transzparencia, analógia [Invariance, transparency, analogy]. Paper presented at the 20 éves az Elméleti nyelvészet szak meeting Eötvös Loránd University Budapest, 25-27

November.[http://budling.nytud.hu/ tork/owncikk/invariancia_handout.pdf]

Törkenczy, Miklós. 2011. Hungarian Vowel Harmony. In M van Oostendorp, C J Ewen, E Hume \& K Rice (eds.), The Blackwell companion to phonology, 2963-2990. Malden, MA \& Oxford: Wiley-Blackwell.

Törkenczy, Miklós. 2013. The close-ups can get rough: exceptional behaviour, transparency and variation in Hungarian vowel harmony. Paper presented at The Twenty-First Manchester Phonology Meeting, Manchester, UK, 23-25

May.http://budling.nytud.hu/ tork/owncikk/torkenczy_manchester_VH_talk.pdf (accessed 14 February 2015).

Törkenczy, Miklós, Péter Rebrus \& Péter Szigetvári. 2013. Harmony that cannot be represented. In J Brandtler, V Molnár \& C Platzack (eds.) Approaches to Hungarian. Volume 13: Papers from the 2011 Lund Conference Volume 13, 229-252. Amsterdam/Philadelphia: John Benjamins.

Vago, Robert M. 1980. The sound pattern of Hungarian. Washington: Georgetown University Press. 